\title{
The Union of Laughter and Forgetting? The European Union and the Construction of its own History
}

\author{
Hernan Tesler-Mabe
}

\begin{abstract}
As recently as one year ago, the European Union was seemingly on a direct path toward its avowed goal of "ever closer union." In numerous publications, EU authorities asserted that they had the confidence of European peoples desirous only of further integration. In the wake of the failed referenda for a European Constitution, however, enthusiasts of European Union can no longer be certain that their enterprise will succeed. The European Union, once strong and united, seems now an entity teetering on the edge of collapse. The reasons for such a dramatic shift are, of course, wide-ranging. Yet I would suggest that a great part of the general European disillusionment with European Union has come about as a result of the actions of the Europeanists themselves. Over the last decades, European officials have exhibited a frightfully high incidence of revisionism in their literature. This practice, I argue, has caused many Europeans to question the integrity of the project of European Union.
\end{abstract}

For my presentation, I intend to undertake a close study of a selection of documents published by the European Communities. In this endeavour, I will compare and contrast the messages imparted in different editions of these works and consider the semiotic significance of the textual and non-textual language appearing therein. In this manner, I hope to achieve two aims. First, I mean to add a corrective element to a literature that, guided by a teleological interpretation of integration, endows integration with"logic" to be found only in hindsight. Second, I intend to examine the many meanings that the EU has had over its history and assess how closely policy has adhered to the ideological goals of prominent Europeanists. In sum, I hope to shed light on the fundamental disconnect between advocates of Europe and the "man on the street" and help establish a dialogue which may contribute to resolving the current impasse within the European Union. 


\section{Introduction}

'Non.' 'Nee.' Two little words, one great furor. In late spring 2005, the initiative for a European Constitution was derailed after a majority of French and Dutch voters voted 'no' in referenda that had been envisioned by the European Communities as "an important step in the construction of Europe.”1 Until this setback, the construction of a new Europe, strong, united and rapidly evolving towards its own vision of a progressive society had seemed to be on course. In numerous publications, the EU authorities asserted that they had the support of a European peoples desirous of a united Europe. ${ }^{2}$ Yet how was the task of convincing Europe's citizenry being accomplished? Institutions of the European Union, buoyed by a profound confidence in their goal of "ever closer union,” persistently produced a literature (propaganda to some, information to others) that explained the campaigns and competences of the European Union and revealed the trajectory of European integration. This literature, however, exhibited a frightfully high incidence of revisionism, being substantively revised from edition to edition to present an ever more “correct” vision of recent European history.

The cost of such a course was altogether too high -- the recent failed initiative for a European Constitution has soundly shaken the self-assurance of European integrationists and led to questioning the means by which the support of the European populace had been obtained. In light of this recent setback, the time has come to revisit

\footnotetext{
1 "A Constitution for Europe" (Luxembourg: Office for Official Publications of the European Communities, 2004), 5.

${ }^{2}$ European opinion polls show that Europe's citizenry has been largely in support of integration -- the percentage of Europeans desiring a unified Europe remained well above the $80 \%$ mark between the years 1952 and 1985. The question posed to assess this feeling has traditionally been, "In general, are you for or against efforts made to unify Western Europe?” More recent sources have replaced “Western Europe” with "Europe" but the results have remained largely unchanged. Jean-Claude Deheneffe, Europe as seen by Europeans: European polling 1973-1986 (second edition) (Luxembourg: Office for Official Publications of the European Communities, 1986), 28.
} 
the integrationist literature and explore the manner in which this body of work has sought to advance European integration. In this article, I undertake a close study of a set of documents published by the European Communities between 1986 and 2000. ${ }^{3}$ Written by authors closely connected to the project of European integration in a format and style suitable for general consumption, bearing the EU imprimatur and dealing extensively with the history of European integration and European history as a whole, these documents serve as a window into an integrationist literature that has aimed at helping to create a unified Europe and to construct a shared European history. By comparing and contrasting the messages imparted in varying editions of these documents, I intend to add a corrective element to an EU literature that, guided by a teleological interpretation of integration, endows many aspects of the integrationist process with a "logic" to be found only in hindsight and reconstitutes European history to accord with present-day objectives. I hope to thus assist in providing a solution to the current integrationist impasse while in the process contributing to a vast academic literature that explores the process of European integration. ${ }^{4}$

\footnotetext{
${ }^{3}$ The works examined are: Pascal Fontaine, Europe -- A Fresh Start: The Schuman Declaration 1950-90 (Luxembourg: Office for Official Publications of the European Communities, 1990); Pascal Fontaine, $A$ new idea for Europe: The Schuman declaration -- 1950-2000 (Luxembourg: Office for Official Publications of the European Communities, 2000); Klaus-Dieter Borchardt, European unification: The origins and growth of the European Community (Luxembourg: Office for Official Publications of the European Communities, 1986); Klaus-Dieter Borchardt, European Integration: The origins and growth of the European Union (Fourth edition) (Luxembourg: Office for Official Publications of the European Communities, 1995); Pascal Fontaine, Europe in Ten Lessons (second edition) (Luxembourg: Office for Official Publications of the European Communities, 1995); Pascal Fontaine, Europe in 10 Points (third edition) (Luxembourg: Office for Official Publications of the European Communities, 1998).

${ }^{4}$ Scholars across disciplines have engaged in an intensive study of European integration. Cultural theorists such as Peter Van Ham, anthropologists and sociologists such as Maryon McDonald and Cris Shore, and political scientists like Mark Pollack have all contributed interesting studies that ruminate on the meanings of the construction of Europe, show the manner in which the European Commission and other organs of the EU contribute to the construction of Europe and shed considerable light on the policy processes and interinstitutional relations involved in the progression of European integration.
} 
Review of European and Russian Affairs vol. 2 issue 4/2006 @ RERA 2006 all rights reserved

\section{Pascal Fontaine's Histories of the Schuman Declaration (1990 \& 2000)}

Pascal Fontaine (b.1948) is a man whose European credentials run strong and deep. Serving as the last assistant to Jean Monnet between 1973 and 1977, by the late 1980s Fontaine had risen to Principal Administrator of the European Parliament. In recent years, Fontaine has been affiliated with the EPP-ED Group (the Group of the European People's Party (Christian Democrats) and European Democrats) in the European Parliament, acting as both Deputy Secretary General to the Party as well as head of the Party's Documentation, Publication and Research Service. In essence, Fontaine is a person possessing a close affiliation and sense of identification with the European project.

Meant to commemorate the $40^{\text {th }}$ and $50^{\text {th }}$ anniversaries of the Schuman Declaration, Pascal Fontaine’s Europe -- A Fresh Start: The Schuman Declaration 195090 (1990) and A New Idea for Europe: The Schuman declaration -- 1950-2000 (2000) are substantially different in terms of how the events of the post-war period in European history have been interpreted by the author. Despite the difference in the works' titles and the different conclusions drawn in the two texts, however, it is clear from the most cursory of glances at the structure and contents of the publications that the latter work is a revision of the earlier text. In sum, the similarities establish the fact that these are merely different editions of the same text while the differences, the examination of which we shall now turn to, in aggregate serve to reconstitute history.

Since the early years of post-war integration, Europeanists have often cast the history of Europe as a continuous sweep in an effort to portray European integration as 
the culmination of a common historical destiny. ${ }^{5}$ It is therefore surprising to find Pascal Fontaine attempting to disassociate the post-war European project from its historical antecedents by altering the passage which relates how "in extending a hand to recent enemies...[Robert Schuman] wiped away the bitterness of war and the weight of the past” (1990, p.5) to "he extended a hand to yesterday's enemies and erased the bitterness of war and the burden of the past” (2000, p.5). With this change, Fontaine effectively demarcates the end of the Second World War as a phenomenon from a distinct historical period which has concluded and calls attention to the Schuman Declaration as the beginning of a new era in European history.

Fontaine's depiction of the Second World War as an event from a different historical period is consistent with a Europeanist discourse that, according to antiintegrationist affiliations such as the Bruges Group, is a blatant offensive aimed at eroding the traditional nation-state building project of the $19^{\text {th }}$ and early $20^{\text {th }}$ centuries. ${ }^{6}$ Such charges are supported by Pascal Fontaine's description of Jean Monnet's career. While Fontaine initially described Jean Monnet's political career in an apologetic manner, admitting that “although [Monnet] never held political office,” (1990, p.10) by the time of the second version of his text, the author attempts to recast it as a positive, saying that Monnet had remained "unfettered by any political mandate” (2000, p.11). By portraying the possession of a "political mandate” as a burden, Fontaine’s subtle change

\footnotetext{
${ }^{5}$ Many examples of this type of literature exist, ranging from textbooks stressing the unity of European history (Les Memoires de L'Europe), to works for children suggesting that today's Europe is far superior to past incarnations (Der Krieg ums Himbeereis) and on to more discursive works such as those written by Denis de Rougement (The Idea Of Europe). See bibliography for full citations.

${ }^{6}$ This discourse, the most obvious examples of which are the initiatives undertaken as a consequence of the 1985 Adonnino Report (such as the creation of an official EU flag and the naming of the choral finale to Beethoven's 9th symphony as the EU's “national” anthem) has resulted in anti-integrationists condemning these actions as attempts at having "the visible emblems of national identity [be] replaced by those of the supranational." Martin Ball, et al, "Federalist Thought Control: The Brussels Propaganda Machine" http://www.brugesgroup.com/news.live?article=79\&keyword=8\#through [accessed 21 December 2004].
} 
strips the nation-state of its role as a traditional source of political authority

Pascal Fontaine’s work bears further evidence of an attempt to erode the import of the nation-state by undermining its agency in the construction of Europe. In 1990, Pascal Fontaine proclaimed that "France is taking the first decisive step to rebuild Europe and is inviting Germany to play its part” (1990, p.13) while in the revised text the sentence is altered to read "France is now taking the first decisive step towards the construction of Europe and is associating Germany in this venture” (2000, p.13). In the new text, therefore, two fundamental changes are found. First, the original text used the verb "rebuild" to imply that European integration was to restore Europe to its pre-war state and solely to fix what had gone wrong. By replacing "rebuild” with "construction," the author implies that the project of European integration is no longer about correcting European problems but has become an attempt to create a new Europe. Second, "invite”, a word suggestive of directorship of a project or activity, is replaced by "associate”, a word used to convey the impression that both parties are part of a larger grouping or project and that neither has control of the enterprise. Europe thus becomes an actor independent of its constituent states.

The discussion of the directorship of the European project dovetails closely with the subject of the democratic deficit and how the EU is often seen as an entity that has assumed control over a wide-ranging set of competences despite having far too few channels through which European citizens can exercise democratic control. With this concern in mind, it comes as a surprise to find Pascal Fontaine revealing in his 1990 text "that the Schuman Plan was the result of a conspiracy" (1990, p.12). Ten years on, numerous institutional changes later and doubtless mindful of the difficulties encountered 
in ratifying the Treaty of Maastricht, this controversial and ill-chosen statement is removed. The historical record is thereby purged of a reference to an act of intrigue that only undermines the EU's credibility in an era during which criticisms of the European Union’s democratic deficit have been bandied about far too regularly to be ignored.?

Pascal Fontaine has also used his texts as a forum for laying out how the European Union's raison d'etre has changed. In 1990, for instance, the European Union was envisioned by the author as an area in which "the merging of economic interests would help to raise the standard of living and pave the way for the establishment of an economic community" (1990, p.13) while ten years on this phrase is changed to read "the fusion of these economic interests will help to raise the standard of living and establish a European Community" (2000, p.15). Via this alteration, the author clearly shows that the economic role of the European Union has been subsumed within the larger goal of creating a community whose form transcends the purely economic sphere.

The moral and religious foundations of modern Europe are also opaquely addressed by the author in his description of one of the founding fathers of European integration. In 1990, Fontaine described Robert Schuman as a "native of Lorraine" (1990, p.10). By 2000, however, Robert Schuman has become both “a native of Lorraine and a Christian" (2000, p.12). One may of course consider Fontaine’s new appellation as merely the personal choice of an author who is, as evidenced by his affiliation with the EPP-ED, fundamentally Christian in outlook. ${ }^{8}$ That possibility, however, should not

\footnotetext{
${ }^{7}$ The democratic deficit is a problem that has over the years increasingly plagued the EU in its quest for legitimacy. Stefan Elbe, for instance, points out that the democratic deficit is a problem that threatens to undermine the European integrationist project. See: Stefan Elbe, Europe: A Nietzschean Perspective (London: Routledge, 2003), 2-3.

${ }^{8}$ The EPP-ED is a European Parliamentarian Party which brings together the Christian Democratic and Conservative parties of Europe. For the religious/political nexus of the EPP-ED, see the tenets professed by the party as well as the numerous ecumenical initiatives they have undertaken.
} 
obscure the fact that for many the construction of Europe also means the construction of a Christian edifice. $^{9}$ Moreover, the possibility that his views are synchronous with those of a majority of Europeans corresponds with the worst fears of those who hold other values or adhere to other religions such as Islam. ${ }^{10}$ Meanwhile, Europeans of the Jewish faith are confronted with the fear of being both excised from the historical record as well as viewing the European Union as a hostile entity that, if not encouraging anti-Semitism, at least allows a space for it. ${ }^{11}$

In sum, the differences between Pascal Fontaine’s 1990 and 2000 texts underline the fact that fundamental changes had taken place in the European Union throughout the 1990s and that by the end of the decade such changes were contributing to a sense of an impending completion to the project of European integration. In 1990, Fontaine felt confident enough to only anticipate the completion of European integration, entitling the final section of his pamphlet “Questions and Answers for tomorrow’s Europe” (1990, p.25). By 2000, the same section of the author's pamphlet has been renamed “Questions for the Europe of the $21^{\text {st }}$ Century,” (2000, p.23) suggesting that Europe has been

\footnotetext{
http://www.epp-ed.org/home/en/aboutus.asp [accessed December 18, 2004].

${ }^{9}$ At a European Study Congress exploring the creation of a European Constitution in June 2002, Pope John Paul II presented a speech in which he stated "Europe will need to draw inspiration with creative fidelity from the Christian roots that have defined European history." "Message of John Paul II to the European Study Congress on the theme: 'Towards a European Constitution?'” http://europa.eu.int/futurum/documents/speech/sp200602_2_en.pdf [accessed 20 December 2004] Intriguingly, information has also come to light that, with the backing of Jacques Chirac, the Diocese of Metz has been working for the last 14 years on a campaign to have Robert Schuman sainted. Ambrose Evans-Pritchard, “Statesman unlikely to become Saint” http://washingtontimes.com/world/20040818094347-6213r.htm [accessed 22 December 2004].

${ }^{10}$ Talal Asad, for instance, has arrived at the conclusion that "Muslims are present in Europe and yet absent from it.” Talal Asad, “Muslims and European Identity: Can Europe Represent Islam?” in The Idea of Europe: From Antiquity to the European Union, ed. Anthony Pagden, (Cambridge: Cambridge University Press, 2002), 209-227.

${ }^{11}$ In January 2004, Romano Prodi found himself having to respond to allegations made by Mr. Cobi Benatoff (Chairman, European Jewish Congress) and Mr. Edgar Bronfman (World Jewish Congress) that some of the positions taken by the European Commission over which he was presiding were anti-Semitic. See: "EU Commission President sets Record Straight on Anti-Semitism" http://www.eurunion.org/news/press/2004/2004001.htm [accessed 18 December 2004].
} 
achieved as well as portending that Europe will be in existence for the course of the $21^{\text {st }}$ century. And while one may choose to view this change as being one that is merely reflective of the arrival of a new millennium, one cannot help but wonder whether such an alteration also reveals a profound confidence in the completion of European integration and a prediction of its permanence.

\section{Klaus-Dieter Borchardt's Histories of European Integration (1986 \& 1995)}

Klaus-Dieter Borchardt's career, like Pascal Fontaine’s, has been closely tied to the European Union. ${ }^{12}$ Borchardt's literature on European integration (European unification: The origins and growth of the European Community (1986) and European Integration: The origins and growth of the European Union (1995)) has meanwhile undergone extensive revision despite seeming sizably unchanged. And while these alterations were, according to the author, meant only to reflect the different times in which the texts were written, I suggest that they reflect not only changes in the course of recent European integration but amount to a sizeable reformulation of European history. ${ }^{13}$

Like Pascal Fontaine, Klaus-Dieter Borchardt must surely be aware that the successful completion of the European project could only be aided by limiting the effect of divisive events in European history. Unlike Fontaine, however, Borchardt chooses not to distance present Europe from the cataclysms of the first half of the European century but, rather, to emphasize these historical events as part of a common history. For instance, the author uses the opportunity to recast the two World Wars as having begun as

\footnotetext{
12 Borchardt (born in 1955) was educated in Law at Hamburg and Berlin, worked with the European Court of Justice between 1990 and 1994, and has served in numerous posts in the Commission from 1987 on. http://ec.europa.eu/commission_barroso/fischer-boel/cabinet/borchardt_en.pdf [accessed June 30, 2006]

13 "[T] he differences between the first and the second edition [sic] are due to the developments of the European Integration between 1986 and 1995.” Klaus-Dieter Borchardt, email to the author, 23 December 2004.
} 
European civil wars. Between the two texts, however, there is a subtle yet fundamental difference; in the 1986 text, "civil wars” (1986, p.6) is presented in quotes, thereby demarcating this as an unofficial version of history, while the 1995 text sees the quotations removed. ${ }^{14}$ In this manner, a heightened level of resonance is added to an interpretation of European history that stresses pan-European connections.

Over the years, the European Union has assumed an ever greater number of competences that have brought into question whether the European Union's (and its predecessors') activities in the economic sphere were meant solely as a first step in a political and cultural unification. ${ }^{15}$ Such suspicions are borne out by Borchardt's discussion of the role of economics in the European Union. In the 1986 text, Borchardt described the EEC as being “concerned with general economic integration” (1986, p.20) while in the 1995 text the author chooses to emphasize how the task of "the European Economic Community -- renamed the 'European Community' under the Treaty of Maastricht...is to mould the Member States into a single Community embracing every sector of the economy” (1995, p.25). In this manner, the author correctly draws attention to the fact that the European Union is no longer to be thought of as an entity in existence primarily for its economic logic but, rather, is to be a single Community whose final shape informs its economy. The textual change, however, collapses the goals of the pre and post-Maastricht eras into one, failing to note how the creation of "a single Community" is a goal that transcends the original compass of the pre-Maastricht era

\footnotetext{
${ }^{14}$ The first text reads: "emerging from the terrible experience of two world wars -- both of which had begun as European 'civil wars"”. The second work reads: "after the terrible experience of two world wars, both of which had begun as European civil wars."

${ }^{15}$ Bernard Connolly, once head of the EMS (Economic Monetary System), National and Community Policies Unit in the Commission, has posited that economic integration was only "part of a programme to subvert the independence -- political as well as economic -- of Europe's countries.” Bernard Connolly, The Rotten Heart of Europe: The Dirty War for Europe's Money (London: Faber and Faber, 1995), xii.
} 
treaties.

Klaus-Dieter Borchardt's belief that the European Union is more than the sum of its economic parts is corroborated by his conflation of the accomplishments of Europe's past with a contemporaneous vision of Europe linked geographically, politically and culturally:

Cultural assets such as the city of Venice, the paintings of Rembrandt, the music of Beethoven or the plays of Shakespeare are an integral part of a common cultural heritage and are regarded as common property by the citizens of Europe. (1995, p.73)

In this manner, Borchardt appropriates the cultural assets heretofore considered fundamental aspects of national cultures and contentiously claims them as an element of a common European heritage while simultaneously stressing the political dimension of European integration.

The social dimension, too, is an area in which Borchardt pursues a line of argumentation that is an imprecise depiction of European history, re-ordering the timeline of integration and thus obscuring the belated entry of social policy into the project of integration. In discussing the social aims of European Union, the author merely declares that "the Treaties did not map out any coherent scheme for a future common social policy” (1995, p.26) when in fact the social dimension of integration only became a topic of serious discussion in the late 1980s. Furthermore, the reason for the exclusion of social policy from the original Treaties is directly attributed to indecision over whether

the establishment of the common market required the broad alignment of social security costs or whether in practice it would inevitably bring the Member States' social security arrangements into line with one another. (1995, p.26)

Borchardt thus ascribes the lack of a coherent social policy to indecision over how best to 
achieve advances in the social sphere when in fact several Member States were reluctant if not downright hostile to the idea of giving up their right to budget and control social security within their borders, this competence having been integral to the consolidation of the nation-state in the early to mid $20^{\text {th }}$ century. ${ }^{16}$

Borchardt's vision of the social dimension of Europe connects with the manner in which the author envisions the European project and its aims. In this discussion, Borchardt explicitly describes what he feels to be the aims of European Unification, albeit differently from edition to edition. In the original text, Borchardt declared that the aim of European unification is:

to preserve and strengthen peace, to achieve economic integration for the benefit of all the peoples of Europe through the creation of a large economic area, and to work towards political union. (1986, p.19)

In the second text, however, this same passage is altered to read:

to preserve and strengthen peace, to achieve economic integration for the benefits of all citizens of the Union through the creation of a single internal market, to work towards political union and, last but not least, to strengthen and promote social cohesion within the Union. (1995, p.23)

In the transition from one passage to the next, we find numerous points of substantial interest. First, social cohesion, while being only a goal of recent vintage, is appended to the other aims (the preservation and strengthening of peace as well as economic integration) that long predate it with only the slightest hint that this is a new policy area. Second, while the first passage makes note of only the geographical connectivity between Europeans -- Europeans being merely those people that inhabit the geographical area that

\footnotetext{
${ }^{16}$ Carl Strikwerda argues that the cataclysm of the First World War led to the creation of a "social citizenship" in which the national governments became the providers of social welfare for their citizens. See: Carl Strikwerda, "Reinterpreting the History of European Integration: Business, Labor, and Social Citizenship in Twentieth-Century Europe,” in European Integration in Social and Historical Perspective: 1850 to the Present, ed. Jytte Klausen and Louise A. Tilly (Oxford: Rowman and Littlefield, 1997), 65.
} 
is Europe -- the more recent text adds a layer of political affiliation, Europeans no longer being described just as "the peoples of Europe" but having become "citizens of the Union.” Third, and perhaps most importantly, Borchardt fails to note that the goals of European integration have undergone any change over time. Thus, while the author's statements are in the strictest sense true, the omission of any mention of change to the goals of European integration obscures the fact that integration is not based upon a set of unchanging goals but an evolutionary process through which new goals have been constantly articulated.

\section{Pascal Fontaine's Europe in Ten Points -- The Images Speak For Themselves}

Up to this point, this study has focused on textual explorations of how Europeanists are revising the historical record. Yet it is not only by way of words that meaning is constructed; images, too, provide us with a means of understanding how changes are being implemented and what these changes mean in aggregate.

No text is more illustrative of an evolution in imagery than Pascal Fontaine's Europe in Ten Lessons. This booklet, having undergone four editions thus far, has expanded from its original edition in which not a single illustration was present to its more recent incarnations in which pictures are utilized to introduce each chapter as well as illustrate key points. For the purposes of this study, I will examine the versions of this text printed in 1995 and 1998 to compare and contrast the meanings of the messages to be found therein.

For ideas to resonate most profoundly in non-textual form, a common motif is often employed as a point of reference. In the 1995 version of Fontaine’s pamphlet, the common motif utilized was that of Homo Europeanus, a stick figure character whose 
European identity is represented by his head being in the form of Europe's twelve stars. ${ }^{17}$ For each of the chapters, Homo Europeanus is depicted performing an action or holding an object that symbolically or metaphorically corresponds with each of the areas under discussion. To take but one example, in the first chapter entitled "A Brief History of European Integration,” our homunculan guide is shown ascending a set of stairs that he himself is drawing (1995, p.5). Common to all the images of Homo Europeanus is a progressivist philosophy, a belief in which historical events are cited as steps leading towards a better future. This philosophy of progress, while tempered somewhat in the last chapter entitled "Europe in the $21^{\text {st }}$ Century: The Shape of Things to Come” (1995, p.40) and shown by way of Homo Europeanus holding a divining mechanism and able to only guess at the final shape of Europe, pervades the illustrative motif employed throughout the pamphlet. ${ }^{18}$

The 1998 incarnation of the pamphlet shows a remarkable reformulation of the unifying motif employed to underline the text's key messages. Entitled "Europe in Ten Points," the new edition witnessed the extinction of Homo Europeanus and his replacement by more fleshed-out, less abstract characters. The European Union, more aware of the dominant position that it was attaining in the world and seemingly freed from the need to prove itself, is portrayed metaphorically as a series of approachable comic characters that reveled in their good-natured demeanor. For instance, whereas the 1995 version of "The Union and the World" portrayed Homo Europeanus standing triumphantly atop a smiling planet earth, the 1998 version of this chapter has a smiling

\footnotetext{
${ }^{17}$ The application of the term Homo Europeanus for the figure represented in the text is my own, although the term, coined by Oswald Spengler (1880-1936), has been bandied about extensively in discussions of European identity.

${ }^{18}$ This uncertain vision of the future is confirmed in the text: "This vision of Europe at the beginning of the 21st century is of necessity speculative and incomplete.” p.41.
} 
Review of European and Russian Affairs vol. 2 issue 4/2006 @ RERA 2006 all rights reserved

man carrying a European flag in his backpack attempting to find his way to the top of the earth (1998, p.47). So too had the display of European strength been tempered; in 1995 "Political Union and Defence” was portrayed as Homo Europeanus flexing his bicep in an explicit show of strength while by 1998 the correspondent chapter proudly displays the EU flag with a dove sitting atop it and holding an olive branch in its mouth (1998, p.33). What is more, instances that continued to have progressivist overtones, such as the man climbing to the top of the world, are deprived of much of their grandiose and selfadulatory projections by way of the softer and more innocent tenor of the illustrative trope employed.

Perhaps the change between the pamphlets, that feeling of confidence so succinctly conveyed in the images, is best encapsulated in the final section of both texts entitled "Key Dates in the History of European Integration.” To accompany this section of text, the 1995 version of the pamphlet portrayed Homo Europeanus pointing to a clock he held in his hands (1995, p.43). By 1998, however, that unimaginative image of the passage of time was replaced by the far more evocative image of a bearded old man pointing to a blue wall with a sole yellow star upon it (1998, p.57). Next to him stands a young girl upon whose head the old man's other hand rests. Here, seemingly, we have the older generation of European, now aware of his European heritage and proud of the European edifice that has been built, explaining to the young girl what it means to be European and recounting the achievements of the European integrationist project. Like the nation-states that had come before it, the European Union had matured to a point at which it possessed its own distinct history that would be passed on from generation to generation. 


\section{Conclusion}

In the course of this paper, we have surveyed a sampling of the textual and nontextual historical revisions in the works of two leading Europeanists, Pascal Fontaine and Klaus-Dieter Borchardt. We have seen how these two authors have attempted to both come to terms with the constantly evolving compass of European Union as well as assist in creating a historical record and logic for its existence. In this bifurcated yet singleminded pursuit, whether discussing the founders of European integration, their aims and ambitions, the steps that have led to the present condition of European integration, or reflecting upon the achievements of European Union, these authors have shown a marked inconsistency and a cavalier approach to European history.

Yet this does not mean, as members of the explicitly anti-European Bruges Group have argued, that this attempt to craft a "new" European history is an exercise in malevolence. ${ }^{19}$ Rather, I would suggest that the authors' revisions are a result of two reasons devoid of any express malevolence but that come as a consequence of a particular world-view. First, I believe that the work of both authors is informed by a progressivist philosophy that underpins their weltanschauung and clearly translates into a sliding perception of reality in which the re-interpretation of history to conform to present-day objectives is not an aberration but an entirely natural phenomenon. Second, I think that Pascal Fontaine, Klaus-Dieter Borchardt and other like-minded Europeanists see their goal of disseminating the message of European Union as sufficiently important and benevolent an enterprise as to demand that they make changes that might facilitate

\footnotetext{
${ }^{19}$ Ball, et al, "Federalist Thought Control."
} 
Review of European and Russian Affairs vol. 2 issue 4/2006 @ RERA 2006 all rights reserved

European integration. I believe that these people genuinely hold the European Union and the values it is to represent in such high regard that they cannot but help write in a manner that is inherently revisionist. Such Europeanists, so involved in their enthusiasm for their project, therefore fail to see the sacrifices they are making to accomplish their goals.

I take exception to the authors' revisionist practices for two reasons. One is the historian's fundamental suspicion of the revision of history when no new findings have been unearthed to corroborate new verdicts. And while it would be foolhardy to posit that history is a "truth" that can ever be lain bare, the authors discussed in this paper have displayed a blatant disregard for established narratives (and even their own earlier conclusions) when little if any evidence exists to substantiate what seem to be little more than present-day agendas and goals. Although I have much sympathy for a united Europe, I feel that any attempts to recast European history in a manner consistent with expressions of continent-wide unity must be grounded in thorough research and circulated with great care. To do otherwise means to mire the debate in a plethora of half-truths and opinions which the European populace would surely not accept.

This connects with my second point. It is my earnest belief that displaying an aggressive form of supra-nationalism that attempts to gloss over or cast aside "traditional" nation-state nationalisms is a tactic that reflects badly upon European integration and is bound to fail. Disregarding the national narratives that have become inexorably intertwined with many a European's sense of identity only serves to drive a wedge between those most devoted to European integration and a sizeable segment of a European populace that, though not opposed to integration per se, finds the attempt to 
weaken national narratives an affront to their identities.

So what is the answer? Luisa Passerini (2003) has recently written that people are in possession of what she calls a "dirty identity," a sense of being and selfcomprehension in which the lines between different forms of affiliation blur and a person's identity becomes a composite of the many forms of identification that they simultaneously bear. I think such an ingenious construction serves as a guide to how we may solve the problem of blending an enthusiasm for Europe with an allegiance to the nation-states of Europe. The height of European nation-building occurred in the latter parts of the $19^{\text {th }}$ century and the beginnings of the $20^{\text {th }}$ century. And while that historical period has long since passed, its repercussions continue to manifest themselves in a deeply felt and often elusive patriotism and a strong allegiance to national narratives. Thus, we must seek to integrate the national narratives upon which these patriotisms are built and include them as part of a European narrative that does not suppress nationalism but expresses how the project of nation building, and even nationalism itself, is a key component of European history. By way of this approach, I believe it possible to accommodate national narratives into a pan-European narrative, a synthesis that would result in the strengthening of Europe by building upon the feelings of community that bind the citizens of Europe's nation-states. 


\section{Bibliography}

\section{Primary Sources}

Official EU Publications:

Borchardt, Klaus-Dieter. European unification: The origins and growth of the European Community. Luxembourg: Office for Official Publications of the European Communities, 1986.

---. European Integration: The origins and growth of the European Union (Fourth edition). Luxembourg: Office for Official Publications of the European Communities, 1995.

A Constitution for Europe. Luxembourg: Office for Official Publications of the European Communities, 2004.

Deheneffe, Jean-Claude. Europe as seen by Europeans: European Polling 1973-1986 (second edition). Luxembourg: Office for Official Publications of the European Communities, 1986.

Fontaine, Pascal. Europe -- A Fresh Start: The Schuman Declaration 1950-90. Luxembourg: Office for Official Publications of the European Communities, 1990.

---. Europe in Ten Lessons. Luxembourg: Office for Official Publications of the European Communities, 1992.

---. Europe in Ten Lessons (second edition). Luxembourg: Office for Official Publications of the European Communities, 1995.

---. Europe in 10 Points (third edition). Luxembourg: Office for Official Publications of the European Communities, 1998.

--. A new idea for Europe: The Schuman declaration -- 1950-2000. Luxembourg: Office for Official Publications of the European Communities, 2000.

A Frontier-Free Europe. Luxembourg: Office for Official Publications of the European Communities, 1988.

Der Krieg Ums Himbeereis: Eine Comic fur junge Leute uber ein friedliches Europe ohne Grenzen. Luxembourg: Amt fur amtliche Veroffentlichungen der Europaischen Gemeinschaften, 1998. 
Other Primary Sources:

De Rougemont, Denis. The Idea of Europe. New York: The MacMillan Company, 1966.

---. Lettre Ouverte aux Europeens. Paris: Editions Albin Michel, 1970.

"EU Commission President sets Record Straight on Anti-Semitism" http://www.eurunion.org/news/press/2004/2004001.htm [accessed 18 December 2004].

Evans-Pritchard, Ambrose. "Statesman unlikely to become Saint." http://washingtontimes.com/world/20040818-094347-6213r.htm [accessed 22 December 2004].

Vivet, Jean-Pierre, ed. Les Memoires de L’Europe. Paris: Robert Laffont, 1970.

Voyenne, Bernard. Histoire de L'Idee Europeenne. Paris: Petite Bibliotheque Payot, 1964.

\section{Secondary Sources}

Asad, Talal. "Muslims and European Identity: Can Europe Represent Islam?” In The Idea of Europe: From Antiquity to the European Union, ed. Anthony Pagden, (Cambridge: Cambridge University Press, 2002), pp.209-227.

Ball, Martin et al. "Federalist Thought Control: The Brussels Propaganda Machine" http://www.brugesgroup.com/news.live?article=79\&keyword=8\#through [accessed 21 December 2004].

Borries, Bodo von. "European History Written by Various European Historians.” In European History: Challenges for a Common Future, ed. Attila Pok, et al. Hamburg: Korber-Stiftung, 2002, pp.22-44.

Connolly, Bernard. The Rotten Heart of Europe: The Dirty War for Europe's Money. London: Faber and Faber, 1995.

Dunkerley, David, et al. Changing Europe: Identities, Nations and Citizens. London: Routledge, 2002.

Elbe, Stefan. Europe: A Nietzschean Perspective. London: Routledge, 2003.

Gowan, Perry \& Anderson, Perry, eds. The Question of Europe. London: Verso, 1997.

Ludlow, N. Piers. "Frustrated Ambitions: The European Commission and the Formation 
of a European Identity, 1958-1967.” In Institutions europeennes et identities europeennes. Brussels: Burylant, 1998, pp.307-325.

Macdonald, Sharon. Approaches to European Historical Consciousness: Reflections and Provocations. Hamburg: Korber-Stiftung, 2000.

McDonald, Maryon. "'Unity in Diversity'. Some tensions in the Construction of Europe.” In Social Anthropology 4, No.1 (1996): 47-60.

Mommsen, Wolfgang J., ed. The Long Way to Europe: Historical Observations from a Contemporary View. Chicago: edition q, inc., 1994.

North, Richard \& Szamuely, Helen. "The Mythology of the EU -- Countered" http://www.brugesgroup.com/news.live?article=242\&keyword=8 [accessed 21 December 2004].

Pagden, Anthony. "Europe: Conceptualizing a Continent.” In The Idea of Europe: From Antiquity to the European Union, ed. Anthony Pagden. Cambridge: Cambridge University Press, 2002, pp.33-54.

Pagden, Anthony, ed. The Idea of Europe: From Antiquity to the European Union. Cambridge: Cambridge University Press, 2002.

Passerini, Luisa, ed. Figures d'Europe: Images and myths of Europe. Bruxelles: P.Lang, 2003.

Pollack, Mark A. "International Relations Theory and European Integration,” Journal of Common Market Studies 39, No. 2 (June 2001): 221-44.

Pok, Attila, et al. European History: Challenges for a Common Future. Hamburg: Korber-Stiftung, 2002.

Shore, Cris. Building Europe: The Cultural Politics of European Integration. London: Routledge, 2000.

---. “European Union and the Politics of Culture” (Paper No.43 -- The Bruges Group) http://www.brugesgroup.com/mediacentre/index.live?article=13\#culture [accessed 19 December 2004]

Strikwerda, Carl. "Reinterpreting the History of European Integration: Business, Labor, and Social Citizenship in Twentieth-Century Europe.” In European Integration in Social and Historical Perspective: 1850 to the Present, eds. Jytte Klausen and Louise A. Tilly. Oxford: Rowman and Littlefield, 1997, pp.51-70.

Van Ham, Peter. European integration and the postmodern condition: governance, democracy, identity. London: Routledge, 2001. 